\title{
DENSITAS ENERGI MAKANAN DAN HEREDITAS SEBAGAI FAKTOR RISIKO HIPERTENSI OBESITIK PADA REMAJA AWAL
}

\author{
Rizka Dyah Ayu Avihani, Muhammad Sulchan*) \\ Program Studi Ilmu Gizi Fakultas Kedokteran Universitas Diponegoro \\ Jl.Dr.Sutomo No.14, Semarang, Telp (024) 8453708, Email : gizifk@undip.ac.id
}

\begin{abstract}
Background: Prevalence of obesity hypertension continues to rise rapidly, especially in adolescence. Dietary energy density and heredity are some of the risk factors of obesity hypertension. The purpose of this study was to determine magnitude of risk factors of dietary energy density and heredity on obesity hypertension occurance on early adolescence.

Method: The study was carried out in SMP 3, SMP 30, SMP Kesatrian 2, and Madrasah Al-Khoiriyah. The design of this study is case-control with the amount of subjects are 72 consist of 36 cases and 36 controls. The subjects were selected that met the inclusion criteria. Data dietary energy density is obtained by interview using food frequency questionnaire last one month. Data on heredity is obtained from measuring of biological parents directly. Height measurements using microtoise, weight using digital scales, and blood pressure using a sphygmomanometer. Results: The prevalence of obesity hypertension is 7.5\%. Found that there is a significant correlation between dietary energy density $(O R=5.8 ; C I=2.013-16.715 ; p=0.001)$ and heredity $(O R=4.0 ; C I=1.518-11.000 ; p=0.004)$ with obesity hypertension occurance on early adolescence.
\end{abstract}

Conclusion: Dietary energy density and heredity are significant risk factor of obesity hypertension on early adolescence, that risk factors are respectively 5.8 times and 4.0 times

Key words: early adolescents; obesity hypertension; dietary energy density; heredity

\begin{abstract}
ABSTRAK
Latar belakang: Prevalensi hipertensi obesitik terus meningkat dengan cepat khususnya pada remaja. Densitas energi makanan dan hereditas merupakan beberapa faktor risiko hipertensi obesitik. Tujuan dari penelitian ini adalah untuk mengetahui besarnya risiko faktor densitas energi makanan dan hereditas terhadap kejadian hipertensi obesitik pada remaja awal.

Metode: Penelitian dilakukan di SMP Negeri 3, SMP Negeri 30, SMP Kesatrian 2, dan Madrasah Al-Khoiriyah. Desain penelitian case-control dengan jumlah subyek 72 yang terdiri dari 36 kasus dan 36 kontrol. Subyek yang dipilih adalah yang memenuhi kriteria inklusi. Data densitas energi makanan didapatkan dengan wawancara menggunakan food frequency questionnaire 1 bulan terakhir. Data hereditas diperoleh dari pengukuran orang tua kandung secara langsung. Pengukuran tinggi badan menggunakan microtoise, berat badan menggunakan timbangan digital, dan tekanan darah menggunakan sphygmomanometer.

Hasil: Prevalensi hipertensi obesitas sebesar 7,5\%. Ditemukan hubungan yang bermakna antara densitas energi $(O R=5,8 ; C I=2,013-16,715 ; p=0,001)$ dan hereditas $(O R=4,0 ; C I=1,518-11,000 ; p=0,004)$ dengan kejadian hipertensi obesitik pada remaja awal.
\end{abstract}

Simpulan: Densitas energi makanan dan hereditas merupakan faktor risiko yang bermakna terhadap kejadian hipertensi obesitik pada remaja awal, dengan besar risiko 5,8 kali dan 4,0 kali.

Kata kunci: remaja awal; hipertensi obesitik; densitas energi makanan; hereditas

\section{PENDAHULUAN}

Hipertensi obesitik adalah suatu kondisi dimana terjadi peningkatan tekanan darah sebagai manifestasi dari akumulasi lemak yang berlebihan pada subkutan dan jaringan lain (obesitas). Hipertensi obesitik bukanlah suatu kesatuan penyakit tersendiri tetapi merupakan suatu kombinasi gejala kompleks dari berbagai sindrom metabolisme berkorelasi dengan kenaikan angka mortalitas, penyakit kardiovaskuler dan diabetes. ${ }^{1,2}$
Prevalensi hipertensi dan obesitas terus meningkat dengan cepat khususnya diantara remaja. Menurut hasil Riset Kesehatan Dasar (RISKESDAS) tahun 2007 prevalensi hipertensi pada remaja sebesar $8,4 \%$, sedangkan prevalensi obesitas yaitu $19,1 \% .^{10}$

Hubungan antara obesitas dan hipertensi pada anak dan remaja telah dilaporkan dimana tekanan darah anak obese lebih tinggi daripada non obese. Penelitian pada anak sekolah di India melaporkan bahwa anak obesitas berisiko tiga kali

${ }^{*}$ Penulis Penanggungjawab 
lebih tinggi mengalami hipertensi dibandingkan anak yang non-obesitas. ${ }^{5}$ Mekanisme hipertensi obesitik telah difokuskan pada tiga mekanisme utama yaitu gangguan pada fungsi sistem saraf otonom, resistensi insulin dan kelainan dalam struktur dan fungsi pembuluh darah. ${ }^{6,7}$

Faktor risiko terjadinya hipertensi obesitik pada remaja adalah interaksi antara faktor keturunan (hereditas) dan faktor lingkungan yang salah satunya adalah asupan makanan dengan densitas energi tinggi. Pengaruh faktor hereditas memainkan peranan dalam perkembangan obesitas. Bila kedua orang tua obesitas, $80 \%$ anaknya menjadi obesitas, bila salah satu orang tua obesitas, prevalensi menjadi $40 \%$ dan bila kedua orang tua tidak obesitas, prevalensi menjadi $14 \%{ }^{4}$

Peningkatan prevalensi obesitas berkaitan dengan peningkatan konsumsi makanan padat energi. ${ }^{8,9}$ Makanan padat energi adalah makanan dengan densitas energi yang tinggi, biasanya tinggi kandungan karbohidrat simpleks, ditambahkan gula dan lemak ${ }^{9}$, sehingga cenderung lezat, murah, dan banyak disukai. Berdasarkan RISKESDAS tahun 2007 di Indonesia, prevalensi makanan berisiko yang paling banyak dikonsumsi oleh anak usia 12-15 tahun adalah penyedap (75,7\%); manis(63,1\%); dan berlemak(13,5\%). ${ }^{10}$ Data tersebut menunjukkan adanya kecenderungan remaja untuk mengkonsumsi makanan padat energi.

Hipertensi obesitik pada usia remaja berisiko tinggi menjadi hipertensi obesitik dimasa dewasa dan berpotensi menderita sindrom metabolik dan penyakit degeneratif dikemudian hari. ${ }^{11,12}$ Berdasarkan uraian diatas, densitas energi dan hereditas merupakan faktor risiko terjadinya hipertensi obesitik pada remaja awal. Tujuan dari penelitian ini adalah untuk menganalisis densitas energi makanan dan hereditas sebagai faktor risiko kejadian hipertensi obesitik pada remaja awal.

\section{METODE PENELITIAN}

Penelitian ini termasuk dalam ruang lingkup keilmuan gizi masyarakat menggunakan desain case control. Pengambilan data meliputi 2 tahap, yaitu pengambilan data awal dan pengambilan data lanjut.

Populasi dalam penelitian ini adalah semua remaja awal usia 12-14 tahun di kota Semarang. Pemilihan sampel ditentukan dengan teknik cluster sampling, sehingga terpilih 5 SMP dari 212 SMP di kota Semarang. Selanjutnya dilakukan proportional random sampling dimana dilakukan pengambilan sampel dari tiap-tiap sub populasi sehingga terpilih SMP N 3, SMP N 30, SMP Kesatrian 2, SMP 10 Nopember 2, dan Madrasah Al-Khoiriyah. Pengambilan data lanjut dilakukan di 4 SMP dimana SMPN 10 Nopember 2 dieksklusi karena prevalensi hipertensi obesitik di SMP tersebut sangat rendah $(0,027 \%)$. Besar sampel dihitung dengan menggunakan rumus kasus kontrol berpasangan dan didapatkan besar sampel minimal 38 kasus dan 38 kontrol, namun subyek yang memenuhi kriteria inklusi yang diteliti hanya 36 subyek. Kasus adalah siswa-siswi yang tergolong hipertensi obesitik sedangkan kontrol adalah siswa-siswi yang lain (teman kasus) yang tidak mengalami hipertensi obesitik. Setiap kasus dicarikan satu kontrol pasangannya yang disetarakan menurut jenis kelamin dan usia. Kriteria inklusi yang digunakan meliputi siswasiswi berusia 12-14 tahun, tidak sedang melakukan puasa atau diet yang ketat, tidak dalam keadaan sakit, dan kooperatif.

Variabel terikat dalam penelitian ini adalah hipertensi obesitik, sedangkan variabel bebas adalah densitas energi makanan dan hereditas. Pengukuran antropometri subyek dilakukan untuk menentukan status gizi berdasarkan BMI-for age percentile. Sedangkan pengukuran tekanan darah subyek dilakukan untuk menetukan status tekanan darah berdasarkan tekanan darah sistolik (TDS) atau tekanan darah diastolik (TDD) persentil menurut usia, jenis kelamin, dan tinggi badan. Kategori status gizi normal jika 5 sampai $<95$ persentil, obesitas jika $\geq 95$ persentil. Sedangkan kategori tekanan darah normal jika TDS dan TDD $\leq 90$ persentil, hipertensi jika TDS dan/atau TDD $\geq 95$ persentil. Hipertensi obesitik adalah keadaan dimana hasil skrining menunjukkan IMT $\geq$ persentil 95 disertai nilai tekanan darah sistolik dan/atau tekanan darah diastolik $\geq$ persentil 95 . $^{13,14}$

Densitas energi makanan adalah jumlah energi dalam berat tertentu dari makanan yang dihitung dengan cara membagi asupan energi total per hari (dalam kkal) dengan berat makanan total yang dikonsumsi (dalam gram). ${ }^{15}$ Data densitas energi makanan diklasifikasikan berdasarkan cutoffs tertile menurut jenis kelamin berdasarkan penelitian Jason, dkk. Asupan makanan untuk perempuan dinyatakan memiliki densitas energi normal apabila makanan yang dikonsumsi dalam sehari memiliki densitas energi 1,45-1,98 kkal/g, dan dinyatakan tinggi apabila densitas >1,99 kkal/g. Klasifikasi untuk laki-laki asupan makanan dinyatakan memiliki densitas energi normal apabila densitas energi 1,53-2,08 kkal/g, dan dinyatakan tinggi apabila densitas $>2,09 \mathrm{kkal} / \mathrm{g} .{ }^{8,15}$ 
Faktor hereditas didefinisikan sebagai faktor keturunan kejadian hipertensi obesitik, yang datanya diperoleh dengan mengukur antropometri dan tekanan darah orang tua kandung subyek. Subyek dikategorikan memiliki hereditas hipertensi obesitas apabila salah satu atau kedua orang tua kandung subyek menderita hipertensi obesitas, sedangkan subyek yang dikategorikan tidak memiliki hereditas hipertensi obesitas adalah subyek yang kedua orang tuanya tidak menderita hipertensi obesitas. Status gizi orang tua subyek dikategorikan berdasarkan WHO Consultation on Obesity, obesitas dinyatakan apabila IMT $\geq 25 .{ }^{11}$ Status tekanan darah dikategorikan berdasarkan grafik British Heart Foundation. ${ }^{16}$

Pengolahan dan analisis data menggunakan program komputer. Analisis univariat untuk mengetahui distribusi frekuensi dari variabel yang diteliti. Analisis bivariat menggunakan Chi Square, kemudian dihitung nilai Odds Ratio (OR).

\section{HASIL PENELITIAN \\ Karakteristik subyek penelitian}

Hasil skrining awal melibatkan 1186 subyek yang berasal dari 5 SMP di Semarang menunjukkan $355(30,03 \%)$ subyek termasuk hipertensi, $155(13,11 \%)$ subyek adalah obesitas, dan $89(7,5 \%)$ subyek termasuk dalam hipertensi obesitik. Penelitian ini melibatkan 72 remaja SMP yang terdiri dari 36 kasus dan 36 kontrol. Karakteristik subyek penelitian dapat dilihat pada tabel 1.

Tabel 1. Karakteristik subyek penelitian

\begin{tabular}{lccccc}
\hline \multirow{2}{*}{ Karakteristik } & \multicolumn{2}{c}{ Kasus } & \multicolumn{2}{c}{ Kontrol } & Total \\
\cline { 2 - 6 } & $\mathbf{N}$ & $\mathbf{\%}$ & $\mathbf{N}$ & $\mathbf{\%}$ & \\
\hline Jenis Kelamin & & & & & \\
$\quad$ Laki-laki & 22 & $61,1 \%$ & 22 & $61,1 \%$ & 44 \\
$\quad$ Perempuan & 14 & $38,9 \%$ & 14 & $38,9 \%$ & 28 \\
$\quad$ Total & 36 & $100 \%$ & 36 & $100 \%$ & 72 \\
Usia & & & & & \\
$\quad 12$ tahun & 4 & $11,1 \%$ & 4 & $11,1 \%$ & 8 \\
13 tahun & 17 & $47,2 \%$ & 17 & $47,2 \%$ & 34 \\
14 tahun & 15 & $41,7 \%$ & 15 & $41,7 \%$ & 30 \\
Total & 36 & $100 \%$ & 36 & $100 \%$ & 72 \\
\hline
\end{tabular}

Tabel 1 menunjukkan subyek berjenis kelamin laki-laki sebanyak 44 anak $(61,1 \%)$ dan perempuan 28 anak $(38,9 \%)$. Subyek yang berusia 12 tahun sebanyak 8 anak $(11,1 \%), 13$ tahun sebanyak 34 anak $(47,2 \%)$ dan 14 tahun sebanyak 30 anak $(41,7 \%)$. Tabel 2 menunjukkan nilai median tekanan darah sistolik pada kasus sebesar $130 \mathrm{mmHg}$ dengan nilai terendah $110 \mathrm{mmHg}$ dan tertinggi $170 \mathrm{mmHg}$, tekanan darah diastolik sebesar $80 \mathrm{mmHg}$ dengan nilai terendah $60 \mathrm{mmHg}$ dan tertinggi $100 \mathrm{mmHg}$ serta IMT/U 98,45 persentil. Sedangkan nilai median tekanan darah sistolik pada kontrol sebesar $100 \mathrm{mmHg}$ dengan nilai terendah $80 \mathrm{mmHg}$ dan tertinggi $120 \mathrm{mmHg}$, tekanan darah diastolik sebesar $60 \mathrm{mmHg}$ dengan nilai terendah $50 \mathrm{mmHg}$ dan tertinggi $70 \mathrm{mmHg}$ serta IMT/U 36,45 pers

entil. Tabel 3 menunjukkan nilai median tekanan darah sistolik pada ayah kasus sebesar $131 \mathrm{mmHg}$, tekanan darah diastolik sebesar $87 \mathrm{mmHg}$ serta IMT $25,50 \mathrm{~kg} / \mathrm{m}^{2}$. Nilai median tekanan darah sistolik pada ibu kasus sebesar $130 \mathrm{mmHg}$, tekanan darah diastolik sebesar $81 \mathrm{mmHg}$ serta IMT $26,82 \mathrm{~kg} / \mathrm{m}^{2}$.

Tabel 2. Nilai median, minimum, maksimum IMT/U (persentil), dan tekanan darah subyek

\begin{tabular}{lcccccc}
\hline \multirow{2}{*}{ Variabel } & \multicolumn{3}{c}{ Kasus } & \multicolumn{3}{c}{ Kontrol } \\
\cline { 2 - 7 } & Median & Min & Max & Median & Min & Max \\
\hline IMT/U & 98,45 & 95,20 & 100,00 & 36,45 & 6,00 & 83,00 \\
Tekanan Darah & & & & & & \\
$\quad$ TDS (mmHg) & 130 & 110 & 170 & 100 & 80 & 120 \\
TDD & 80 & 60 & 100 & 60 & 50 & 70 \\
$\quad(\mathrm{mmHg})$ & & & & & & \\
\hline
\end{tabular}


Tabel 3. Nilai median, minimum, maksimum tekanan darah, dan IMT orang tua kandung subyek

\begin{tabular}{lcccccc}
\hline \multirow{2}{*}{ Variabel } & \multicolumn{3}{c}{ Kasus } & & Kontrol \\
\cline { 2 - 7 } & Median & Min & Max & Median & Min & Max \\
\hline IMT & & & & & & \\
$\quad$ Ayah & 25,50 & 20,50 & 39,62 & 23,60 & 18,41 & 35,96 \\
$\quad$ Ibu & 26,82 & 20,80 & 34,10 & 26,46 & 16,80 & 30,80 \\
TDS (mmHg) & & & & & & \\
$\quad$ Ayah & 131 & 110 & 229 & 130 & 110 & 220 \\
$\quad$ Ibu & 130 & 96 & 200 & 130 & 100 & 184 \\
TDD (mmHg) & & & & & & \\
$\quad$ Ayah & 87 & 70 & 129 & 80 & 70 & 120 \\
$\quad$ Ibu & 81 & 64 & 110 & 81 & 69 & 109 \\
\hline
\end{tabular}

Densitas energi makanan sebagai faktor risiko hipertensi obesitik

Rerata densitas energi makanan kelompok kasus adalah 2,12 $\pm 0,30$ sedangkan kelompok

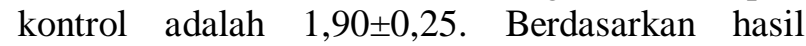
tersebut menunjukkan bahwa kelompok kasus cenderung memiliki asupan makanan dengan densitas energi yang lebih tinggi daripada kelompok kontrol. Subyek dengan asupan makanan berdensitas energi tinggi sebanyak 28 anak $(38,9 \%)$ sedangkan subyek dengan asupan makanan berdensitas energi normal sebanyak 44 anak $(61,1 \%)$. Sebanyak 21 subyek $(75 \%)$ dengan asupan makanan berdensitas energi tinggi mengalami hipertensi obesitik. Hasil uji statistik menujukkan bahwa densitas energi makanan $(\mathrm{p}=0,001 ; \mathrm{OR}=5,8)$ merupakan faktor risiko kejadian hipertensi obesitik pada remaja awal. Hal ini berarti remaja yang memiliki asupan makanan dengan densitas energi yang tinggi berisiko 5,8 kali lebih besar menjadi hipertensi obesitik.

Tabel 4. Hubungan densitas energi makanan dengan hipertensi obesitik

\begin{tabular}{lccccccc}
\hline & \multicolumn{2}{c}{ Kasus } & \multicolumn{2}{c}{ kontrol } & \multirow{2}{*}{ p } & \multirow{2}{*}{ OR } & \multirow{2}{*}{$95 \% \mathrm{CI}$} \\
\cline { 2 - 5 } & $\mathrm{N}$ & $\%$ & $\mathrm{~N}$ & $\%$ & & & \\
\hline Densitas energi & & & & & & & \multirow{2}{*}{$2,013-$} \\
$\quad$ Tinggi & 21 & 58,3 & 7 & 19,4 & 0,001 & 5,800 & 16,715 \\
$\quad$ Normal & 15 & 41,7 & 29 & 80,6 & & & \\
\hline
\end{tabular}

\section{Hereditas sebagai faktor risiko hipertensi obesitik}

Dari tabel 5 dapat diketahui bahwa sebagian besar subyek kasus memiliki hereditas hipertensi obesitik dari ayah dan atau ibu kandung sebanyak 26 anak $(72,2 \%)$ dan sebagian besar subyek kontrol tidak memiliki hereditas hipertensi obesitik yaitu sebanyak 22 anak $(61,1 \%)$. Hasil analisis bivariat menunjukkan bahwa hereditas merupakan faktor risiko kejadian hipertensi obesitik dengan $\mathrm{p}<0,05$ dan OR 4,0. Hal ini menunjukkan bahwa remaja yang memiliki hereditas hipertensi obesitik dari orang tua kandungnya berisiko 4 kali lebih besar menjadi hipertensi obesitik.

Tabel 5. Hubungan hereditas dengan hipertensi obesitik

\begin{tabular}{lccccccc}
\hline & \multicolumn{2}{c}{ Kasus } & \multicolumn{2}{c}{ Kontrol } & \multirow{2}{*}{$\mathrm{p}$} & \multirow{2}{*}{ OR } & \multirow{2}{*}{$95 \% \mathrm{CI}$} \\
\cline { 2 - 5 } & $\mathrm{N}$ & $\%$ & $\mathrm{~N}$ & $\%$ & & & \\
\hline Hereditas & 26 & 72,2 & 14 & 38,9 & $0,004^{*}$ & 4,086 & $1,518-$ \\
$\quad$ Ada & 10 & 27,8 & 22 & 61,1 & & & 11,000 \\
$\quad$ Tidak ada & 10 & & & & & &
\end{tabular}




\section{PEMBAHASAN}

Penelitian pendahuluan terhadap 1186 subyek diketahui prevalensi kejadian hipertensi obesitik pada remaja awal usia 12-14 tahun sebesar 7,5\%. Prevalensi hipertensi pada anak obese ini lebih tinggi dibandingkan dengan penelitian yang dilakukan di SMP swasta di Semarang pada tahun 2006, yang menjumpai prevalensi obesitas dengan hipertensi pada anak usia $12-14$ tahun sebesar $6,3 \% .^{18}$ Meningkatnya kejadian hipertensi obesitik menunjukkan bahwa hipertensi obesitik merupakan masalah yang sedang berkembang pada usia pubertas. Remaja dengan hipertensi obesitik dapat meningkatkan risiko terjadinya sindrom metabolik, dan komplikasi penyakit yang ditimbulkan oleh sindrom metabolik, seperti diabetes mellitus tipe 2, penyakit jantung koroner (PJK), stroke, gagal jantung, sindrom ovarium polikistik (PCOS), dan perlemakan hati (fatty liver) non-alkoholik yang salah satunya adalah non alcoholic steato hepatitis (NASH). ${ }^{19}$

\section{Densitas energi makanan sebagai faktor risiko hipertensi obesitik}

Remaja terutama di kota besar mengalami pergeseran pola makan dari pola makan tradisional ke pola makan barat. Pemilihan makanan pada remaja tidak lagi didasarkan pada kandungan gizi, tetapi lebih banyak dipengaruhi oleh sosialisasi antar teman sebaya. Umumnya remaja cenderung mengkonsumsi makanan dengan densitas energi yang tinggi yang biasanya tinggi kandungan karbohidrat simpleks, ditambahkan gula dan lemak. $^{9}$

Meskipun beberapa makanan padat energi sehat, namun ternyata lebih banyak makanan padat energi tidak sehat yang justru banyak dipilih dan dikonsumsi kalangan remaja. Makanan padat energi yang sehat contohnya adalah kacangkacangan, biji-bijian, alpukat, telur, kentang, susu, dan minyak zaitun. ${ }^{20}$ Makanan padat energi yang tidak sehat disebut makanan padat energi rendah gizi (Energy-dense, nutrient-poor foods (EDNP)). EDNP dikategorikan menjadi 5 jenis, yaitu: visible fat (margarin, mentega, minyak, krim, saus dressing, gajih, steak, sosis, dan makanan yang digoreng); sweeteners (gula, sirup, permen, minuman manis); dessert (biskuit, kue, pie, pastry, donat, es krim, milkshake, puding, kue keju); snack asin (keripik kentang, keripik jagung, tortilla); dan lain-lain (kopi, teh, kaldu, saus tomat, saus sambal). ${ }^{21}$

Konsumsi makanan dengan densitas energi yang rendah mampu menurunkan asupan energi total. ${ }^{8}$ Sedangkan konsumsi makanan dengan densitas energi yang tinggi secara berlebihan berkontribusi dalam peningkatan asupan energi total dan turut menyebabkan keseimbangan energi yang positif. ${ }^{22,23}$ Penelitian di Amerika pada subyek dengan asupan makanan berdensitas energi rendah memiliki asupan energi total yang lebih rendah (275-425 kkal/hari lebih rendah) dibandingan subyek dengan asupan makanan berdensitas energi tinggi, meskipun mereka mengkonsumsi makanan lebih banyak (300-400 gram/hari lebih banyak). ${ }^{8}$ Kebiasaan senang makan makanan dengan densitas energi yang tinggi memungkinkan tubuh memperoleh tambahan energi sehingga tanpa disadari asupan energi ke dalam tubuh melebihi kebutuhan dan dampaknya berupa bertambahnya timbunan lemak dalam tubuh. Kebiasaan seperti itu akan memudahkan terjadinya obesitas. Banyaknya lemak dalam tubuh menyebabkan pembuluh darah menyempit sehingga dapat meningkatkan tekanan darah. Selain itu obesitas juga terkait dengan level insulin yang tinggi yang mengakibatkan tekanan darah meningkat.

Makanan atau minuman manis mengandung unsur karbohidrat sederhana yang menghasilkan energi tinggi. Fruktosa (gula sederhana yang menghasilkan rasa manis), tidak memberikan efek kepuasan setelah makan. Seseorang yang mengkonsumsi makanan/minuman manis tidak akan merasa puas dan akan makan terus menerus. Konsumsi yang berlebihan akan meningkatkan asupan energi yang selanjutnya disimpan tubuh sebagai cadangan lemak. Penumpukan lemak tubuh pada perut akan menyebabkan obesitas sentral, sedangkan penumpukan pada pembuluh darah akan menyumbat peredaran darah dan membentuk plak (aterosklerosis) yang berdampak pada hipertensi dan jantung koroner. Konsumsi jenis pangan yang digoreng (deep frying) berpengaruh meningkatnya asupan energi dari lipid. Makanan yang digoreng memiliki rasa yang gurih, renyah, enak dan kaya lemak. Hal ini menyebabkan seseorang ingin makan terus menerus, sehingga memiliki asupan energi yang tinggi dan tingkat kepuasan yang rendah. Rendahnya tingkat kepuasan dapat berpengaruh terhadap kemampuan respon insulin dan leptin, hormon yang menstimulasi rasa laparkenyang. $^{24,25}$

Hasil Food Frequency Questionare (FFQ) dalam penelitian ini menunjukkan baik kasus dan kontrol lebih menyukai makanan dengan densitas energi yang tinggi seperti mi instan (densitas $=3,7$ $\mathrm{kkal} / \mathrm{g}$ ), fried chicken (densitas $=3,3 \mathrm{kkal} / \mathrm{g}$ ), bakso 
(densitas $=3,7 \mathrm{kkal} / \mathrm{g}$ ), roti manis (densitas $=2,8$ $\mathrm{kkal} / \mathrm{g}$ ), dan gorengan (densitas=2,0 $-3,4 \mathrm{kkal} / \mathrm{g}$ ). Asupan makanan dikatakan berdensitas tinggi (padat energi) jika rata-rata densitas energi $>2,09$ $\mathrm{kkal} / \mathrm{g}$ untuk laki-laki dan $>1,99 \mathrm{kkal} / \mathrm{g}$ untuk perempuan. ${ }^{8,15}$ Penelitian ini ditemukan adanya hubungan antara densitas energi makanan dengan kejadian hipertensi obesitik $(\mathrm{p}=0,001)$ dimana remaja yang asupan makanannya berdensitas energi tinggi berisiko 5,8 kali lebih besar untuk mengalami hipertensi obesitik. Hasil penelitian ini sejalan dengan penelitian di Amerika Serikat yang menemukan bahwa konsumsi makanan padat energi berhubungan dengan obesitas dan gangguan terkait sindrom metabolik. ${ }^{8,15}$

\section{Hereditas sebagai faktor risiko hipertensi obesitik}

Adanya faktor hereditas atau riwayat obesitas dan hipertensi pada keluarga tertentu menyebabkan keluarga itu mempunyai risiko menderita hipertensi obesitik. Kasus hipertensi esensial $70 \%-80 \%$ diturunkan dari orang tuanya. Jika salah satu dari orang tua memiliki riwayat hipertensi maka memiliki kemungkinan 25\% terkena hipertensi. ${ }^{6}$ Bila kedua orang tua obesitas, $80 \%$ anaknya menjadi obesitas, bila salah satu orang tua obesitas, kejadian obesitas menjadi $40 \%$ dan bila kedua orang tua tidak obesitas, prevalensi menjadi $14 \%{ }^{4}$

Hipertensi merupakan salah satu gangguan genetik yang bersifat kompleks. Ekspresi dari hipertensi pada seseorang merupakan hasil dari perubahan-perubahan pada genetik. Faktor keturunan berpengaruh terhadap hipertensi primer melalui beberapa gen yang terlibat dalam regulasi vaskular dan reabsorpsi natrium oleh ginjal. Efek poligenik misalnya, dihasilkan dari peningkatan fungsi mutasi dan polimorfisme pada penerjemahan komponen gen atau pengaturan molekul-molekul pada sistem renin-angiotensin dan transpor natrium ginjal. ${ }^{26,27}$

Parental fatness merupakan faktor genetik yang berperan besar terhadap kejadian obesitas. Kadar serum leptin pada orang obese tinggi sehingga menimbulkan hipotesis bahwa insensitivitas terhadap leptin mengakibatkan perkembangan progresif obesitas pada orang yang overweight. Mutasi dan polimorfisme gen dan neuropeptida lain dan regulasi neurohormonal selera makan dan kontrol berat badan telah ditemukan pada obesitas, bahwa mutasi proopiomelanocorticotropin (POMC) gen dan polimorfisme reseptor adrenegik $\beta$, MC4R berhubungan dengan obesitas berat dan morbiditas. ${ }^{28}$ Penelitian lain tentang mekanisme kerentanan genetik terhadap obesitas adalah melalui efek pada resting metabolic rate (RMR), proses pembakaran dalam tubuh diluar kegiatan olahraga (thermogenesis non exercise), kecepatan oksidasi lipid dan kontrol nafsu makan yang jelek. Dengan demikian kerentanan terhadap obesitas ditentukan secara genetik sedang lingkungan menentukan ekspresi fenotip. ${ }^{29}$

Penelitian ini ditemukan hubungan yang bermakna antara faktor hereditas dengan kejadian hipertensi obesitik $(\mathrm{p}=0,004)$ dimana anak dengan orang tua yang menderita hipertensi obesitik memiliki risiko 4 kali untuk mengalami hipertensi obesitik. Hal ini sesuai dengan penelitian di Amerika menunjukkan bahwa obesitas pada usia 10-14 tahun dengan salah satu orang tuanya obesitas, $79 \%$ akan menjadi obesitas dewasa. ${ }^{30}$ Penelitian pada remaja di India didapatkan bahwa 37,5\% kejadian hipertensi berhubungan dengan adanya riwayat hipertensi dari orang tua. ${ }^{31}$

\section{SIMPULAN}

1. Prevalensi hipertensi obesitik pada remaja awal sebesar 7,5\%.

2. Subyek yang memiliki asupan makanan dengan densitas energi tinggi berisiko 5,8 kali lebih besar mengalami hipertensi obesitik.

3. Subyek yang memiliki hereditas hipertensi obesitik berisiko 4 kali lebih besar mengalami hipertensi obesitik.

\section{SARAN}

Untuk mencegah terjadinya hipertensi obesitik pada remaja dapat dilakukan sejak usia dini salah satunya dengan mengatur asupan makanan yaitu dengan membatasi konsumsi makanan berdensitas energi tinggi. Selain itu, perlu dilakukan monitoring tekanan darah dan status gizi secara berkala melalui Usaha Kesehatan Sekolah (UKS).

\section{DAFTAR PUSTAKA}

1. Editorial. Insulin Resistance Syndrome in Children and Adolescents: Clinical Meaning and Indication for Action. International Journal of Obesity. 2004; 28:829-832

2. Behrman, Kliegman, Arvin. Ilmu Kesehatan Anak Vol. 1 Edisi 15. Editor edisi bahasa Indonesia: Samik Wahab, et al. Jakarta: EGC; 1999

3. Rena I. Kosti, Demosthenes B. Panagiotakos. The Epidemic Of Obesity In Children And Adolescents In The World. Cent Eur J Publ Health 2006; 14 (4): 151-159. 
4. Syarif, D.R. 2003. "Childhood Obesity: Evaluation and Management". Surabaya: Naskah Lengkap National Obesity Symposium II: 123-39.

5. Gulati Sanjeev. Childhood Hypertension. Indian Pediatrics 2006;43:326-333

6. Sorof $\mathbf{J}$ and Stephen D. Obesity Hypertension in Children: A Problem of Epidemic Proportions. Hypertension 2002; 40:441-447

7. McCance KL, Huether SE. Pathophysiology the biologic basis for disease in adults and children. fifth edition: Elsevier mosby.2006.p.1409-4,10864,1173

8. Jason H Ledikwe, et al. Dietary Energy Density is Associated with Energy Intake and Weight Status in US Adults. Am J Clin Nutr 2006; 83:1362-8

9. Kant AK, Graubard BI: Energy density of diets reported by Americans adults: association with food group intake, nutrient intake, and body weight. Int J Obes Relat Metab Disord 29:950-956, 2005

10. Badan Litbang Kesehatan Departemen Kesehatan RI. Laporan Hasil Riset Kesehatan Dasar (RISKESDAS) Nasional 2007. Jakarta.

11. WHO. Obesity: Preventing and Managing The Global Epidemic, WHO Technical Report Series 2000; 894, Geneva.

12. Heird, W.C. Parental Feeding Behavior and Children's Fat Mass. Am J Clin Nutr, 2002; 75: 451-452.

13. Centers of Disease Control and Prevention. About BMI for Children and Teens. 2011. Available from: URL:

http://www.cdc.gov/healthyweight/assessing/bmi/c hildrens_bmi/about_childrens_bmi.html

14. Wardlow GM, Smith AM. Nutrition from Infancy Through Adolescence. Dalam: Wardlow GM, Smith AM. Contemporary Nutrition 7th edition. 2009.p.588-590

15. Jason A. Mendoza, et al. Dietary Energy Density is Associated with Obesity and The Metabolic Syndrome in U.S. Adults. American Diabetes Association 2007; 30: 974-78

16. British Heart Foundation. Blood Pressure Charts. [serial online] 2007. Available from: http://www.heartstats.org/temp/Tabsp9.2spweb07

17. M Verma, J Chhatwal, SM George. Obesity and Hypertension in Children. Indian Pediatrics. 1994; 31:1065-1068

18. Christianus Wagesetiawan. Hubungan Tingkat Hipertensi dengan Kejadian Mikroalbuminuria pada Anak Obesitas Usia 12-14 Tahun. Tesis. Semarang: Universitas Diponegoro Program Pasca Sarjana Magister Ilmu Biomedik dan PPDS1; 2007

19. Bethene, Ervin. Prevalence of Metabolic Syndrome Among Adults 20 Years of Age and Over, by Sex, Age, Race, and Ethnicity, and Body Mass Index: United Stated, 2003-2006. 2009. Division of Health and Nutrition Examination Surveys

20. Shereen Jegtvig. What Does Energy-Dense Mean? Medical Review Board 2012. Available from:
http://nutrition.about.com/od/gettingstarted/f/WhatIs-Energy-Density.htm

21. Ashima K Kant. Consumption of energy-dense, nutrient-poor foods by adult Americans: nutritional and health implications. The third National Health and Nutrition Examination Survey, 1988-1994. The American Journal of Clinical Nutrition 2000; 72:929-36

22. Jacob C Seidell, Tommy LS Visscher. Aspek Kesehatan Masyarakat pada Gizi Lebih. Dalam Buku : Gizi Kesehatan Masyarakat. Jakarta:Penerbit Buku Kedokteran EGC; 2005.p.203-15

23. Ashima K. Reported Consumption of LowNutrient-Density Foods by American Children and Adolescents. Arch Pediatr Adolesc Med/Vol 157; 2003

24. Johnson et al. 2007. Potential role of sugar (fructose) in the epidemic of hypertension, obesity and the metabolic syndrome, diabetes, kidney disease, and cardiovascular disease. Am J Clin Nutr 86:899-906.

25. Farida Nur Aisyiyah. Faktor Risiko Hipertensi pada Empat Kabupaten /Kota dengan Prevalensi Hipertensi Tertinggi di Jawa dan Sumatera. Skripsi. 2009. Departemen Gizi Masyarakat Fakultas Ekologi Manusia Institut Pertanian Bogor.

26. Adrogue, H.J., and Madias, N.E. Sodium and Potassium in the Pathogenesis of Hypertension. The New England Journal of Medicine. 2007; 356: p1966-78. Available from: http://content.nejm.org/cgi/reprint/356/19/1966.pdf

27. Lam TC, Cheung BMY, Chung SSM. Genetic factors of hypertension. Med Progress 2001; 10:116.

28. Kiess W, Reich A, Muller G, Meyer K, Galler A, Bennek $J$, et al. Clinical aspects of obesity in childhood and adolescence-diagnosis, treatment, and prevention. International Journal of Obesity. 2001; 25(1): 575-79

29. Kopelman,G.D. Obesity as a Medical Problem, NATURE, 2000; 404: 635-43.

30. Whitaker, R.C.,et al. Predicting Obesity in Young Adulthood from Childhood and Parental Obesity, N Engl J Med, 1997; 337: 869 -73

31. Soudarssanane MB, Karthigeyan M, Stephen S, Sahai A. Key predictors of high blood pressure and hypertension among adolescents: a simple prescription for prevention. Indian Journal of Community Medicine 2006;31(3):164-169 